\section{Irrigation Scheduling to Increase Muskmelon Fruit Biomass and Soluble Solids Concentration}

\author{
Robert L. Long, Kerry B. Walsh, and David J. Midmore \\ Plant Sciences Group, Central Queensland University, Rockhampton, QLD \\ 4702, Australia
}

Gordon Rogers ${ }^{1}$

Faculty of Agriculture, Food and Natural Resources, University of Sydney, NSW 2006, Australia

Additional index words. rockmelon, muskmelon, cantaloupe, fruit quality, water status

\begin{abstract}
A common practice for the irrigation management of muskmelon (Cucumis melo L. reticulatus group) is to restrict water supply to the plants from late fruit development and through the harvest period. However, this late fruit development period is critical for sugar accumulation and water stress at this stage is likely to limit the final fruit soluble solids concentration (SSC). Two field irrigation experiments were conducted to test the idea that maintaining muskmelon plants free of water stress through to the end of harvest will maximise sugar accumulation in the fruit. In both trials, water stress before or during harvest detrimentally affected fruit SSC and fresh weight (e.g., no stress fruit $11.2 \%$ SSC, weight $1180 \mathrm{~g}$; stress fruit $8.8 \%$ SSC, weight $990 \mathrm{~g}$ ). Maintaining plants free of water stress from flowering through to the end of harvest is recommended to maximise yield and fruit quality.
\end{abstract}

Poor eating quality is the main reason given by consumers for why they do not purchase more muskmelon(Cucumis melo L. reticulatus group) in Australia (Australian Melon Association, 2003). One criterion commonly used to assess fruit eating quality is soluble solids concentration (\% SSC) of the flesh. Mutton et al. (1981) recommended a minimum SSC of $10 \%$, while a U.S. standard recommends a minimum of $9.0 \%$ (Kader, 2002).

We have sought to reconsider agronomic practices employed in muskmelon production in Australia, with a focus on fruit SSC as well as fruit biomass yield (Long et al., 2004). In the current study we consider the influence of plant water status, working with the base that the standard practice for muskmelon production in Australia is to restrict water supply to the plants from late fruit development and through the harvest period (Hulme et al., 2002; Lovatt et al., 1997).

In early fruit development, assimilate from photosynthesis is directed mainly into fruit growth, and it is only in the final two weeks of fruit development, after fruit expansion has ceased, that sugars accumulate in the fruit resulting in an increase in SSC. This carbohydrate partitioning is regulated by high soluble

Received for publication 9 Nov. 2005. Accepted for publication 26 Dec. 2005. The authors thank OneHarvest and Horticulture Australia Limited for providing financial support (Project No. VX00019 Development of a crop management program to improve the sugar-content and quality of rockmelons). We gratefully acknowledge Robert Gray of OneHarvest for his encouragement, and we thank the melon grower Phil Mansell for allowing us to conduct field experiments on his property.

${ }^{1}$ Enquiries and reprint requests: grogers@usyd. edu.au. acid invertase activity during fruit growth and then by high sucrose phosphate synthase activity during the sugar accumulation phase (Lester et al., 2001).

Muskmelon do not accumulate significant amounts of starch, so all carbohydrate for fruit growth or sugar accumulation must come from current photosynthesis in the source leaves (Wein, 1997). Thus the impact of a source or sink manipulation on muskmelon fruit quality and harvestable yield will depend on the timing of the manipulation or stress (El-Keblawy and Lovett-Doust, 1996; Long et al., 2004; Valantin et al., 1998) and it is well known that water stress reduces stomatal conductance and the rate of photosynthesis in mature source leaves (Heermann et al., 1990).

Therefore it is expected that water stress during vegetative growth will reduce the photosynthetic capacity of the plant, and thus potentially reduce harvestable fruit biomass. Water stress during early fruit development may affect fruit cell number, and thus final fruit size (Higashi et al., 1999). Importantly, stress imposed during the later part of fruit development, during the sugar accumulation phase following fruit cell expansion, is expected to have the greatest impact on fruit SSC relative to the impact on fruit biomass (Long et al., 2004).

The impact of plant water status during the life of muskmelon crops on fruit quality and yield parameters has been variously reported in the literature. Wells and Nugent (1980) reported that rainfall in the final stages of fruit development affected muskmelon SSC either positively or negatively, depending on cultivar, and that SSC was most influenced by rainfall during the $5 \mathrm{~d}$ preceding harvest. Phene et al. (1987) imposed different water deficit regimes during vegetative growth using several irrigation practices (subsurface, high frequency surface, and low frequency surface trickle) and reported no effect on fruit SSC between treatments. Other quality factors such as ground spot and fruit rot were differentially affected by treatments.

In this study, the effect of imposing water stress before and during harvest on muskmelon yield and fruit SSC was tested in two separate field experiments.

\section{Materials and Methods}

\section{Experiment 1}

Plant culture. The first experiment was planted on 22 Feb. 2001 on a commercial farm near Bourke, New South Wales, Australia (lat. $30^{\circ} 2^{\prime}$ 'S long. $145^{\circ} 57^{\prime} \mathrm{E}$ ). 'Dubloon' muskmelon plants were established by transplanting through black plastic mulch at $50 \mathrm{~cm}$ spacing into single row beds $2 \mathrm{~m}$ between centres into which trickle irrigation tube had been previously buried to a depth of $30 \mathrm{~cm}$ and preplant fertilizer applied. The field sites were uniform in soil type and laser-levelled. The soil was a red sandy loam. Total preplant base and fertigated nutrients applied during the crop were $50 \mathrm{~N}$, $17 \mathrm{P}, 113 \mathrm{~K}$, and $15 \mathrm{Ca} \mathrm{kg} \cdot \mathrm{ha}^{-1}$.

Irrigation water was from the Murray Darling River, and the electrical conductivity of the water was 500 to $700 \mu \mathrm{S} . \mathrm{cm}^{-1}$. After an initial irrigation at transplant, all treatments were maintained between field capacity and the refill point from flowering until one week before the start of harvest. Irrigation deficit (water stress) treatments were imposed as follows: 1) no stress, 2) stress during the week before the start of harvest, 3 ) stress from one week before the start of harvest including the harvest period. Tensiometers were installed to $25 \mathrm{~cm}$ depth to measure soil moisture. Soil moisture was maintained between 10 and 15 $\mathrm{kPa}$ of soil suction, but allowed to dry to 40 $\mathrm{kPa}$ for the stress periods.

Experimental design. The experiment was three treatments in a Completely Randomised Design with four replications. Individual plots were $10 \mathrm{~m}$ long, and a 2-m-long section of row was selected from each plot and all fruit were harvested for yield and fruit quality measurements. There would have been minimal movement of water between adjacent plots. Muldoon et al. (1999) reported that for muskmelon plants growing in clay soil with a trickle tube $10 \mathrm{~cm}$ deep, water moved laterally only about $40 \mathrm{~cm}$ from the trickle tube. From our observations during the experiments, the lateral movement of water was $<35 \mathrm{~cm}$ from the buried trickle tube. Moreover, if any lateral leakage of irrigation water into adjacent plots had occurred, it would have minimised water stress treatment effects, not accentuated them.

\section{Experiment 2}

Plant culture. The second experiment was set up on the same farm but in the following year and on a heavy clay soil. The plants were established by direct seeding into bare soil on 30 Nov. 2001 at $50 \mathrm{~cm}$ spacing into single row 
beds $2 \mathrm{~m}$ between centers into which trickle irrigation tube had been previously buried to a depth of $30 \mathrm{~cm}$ and preplant fertilizer applied. The field site was uniform in soil type and laser-levelled. Total preplant base and fertigated nutrients applied during the crop were the same as for Expt. 1.

Soil moisture was measured using a single capacitance-based Enviroscan (SentekAustralia) soil moisture probe per treatment. Each probe had sensors at 10,20, and $50 \mathrm{~cm}$ depth. The field capacity of the soil was $50 \mathrm{~mm}$ of soil water per $10 \mathrm{~cm}$ soil depth and the refill point was about $15 \mathrm{~mm}$ of soil water per $10 \mathrm{~cm}$ soil depth. After an initial irrigation at sowing, all treatments were maintained between field capacity and the refill point from flowering until one week before the start of harvest. Water stress was defined as allowing soil to dry to 8 to $10 \mathrm{~mm}$ soil water per $10 \mathrm{~cm}$ soil depth at 20 $\mathrm{m}$. Water stress treatments were 1) no stress, 2) stress imposed at the start of harvest, 3) stress during the week before the start of harvest, and 4) stress during the week before harvest and including the harvest period.

Experimental design. The experiment was set up with 4 treatments in a split-block design with 3 blocks, each having 2 cross treatments, giving a total of 24 plots. Individual plots were $10 \mathrm{~m}$ long, and a 2-m-long section was selected from each plot for yield and fruit quality measurements.

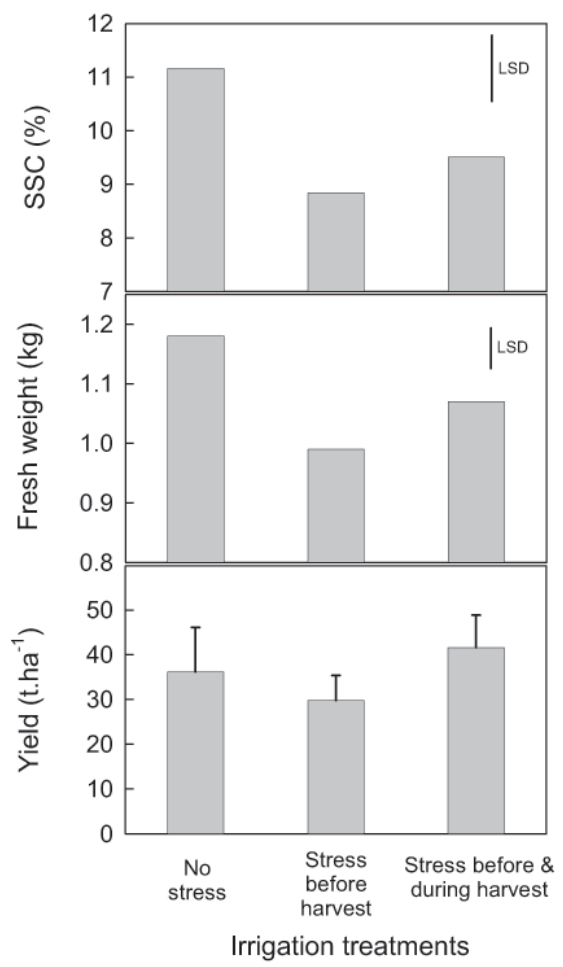

Fig. 1. Experiment 1. Mean and LSD $(P=0.05)$ values for fruit soluble solids concentration (SSC) and fresh weight (ANOVA $P<0.01$ ); mean and corresponding SE values are reported for yield (ANOVA $P=0.42$ ). Irrigation deficit treatments were imposed during the week before the start of harvest (stress before harvest), and from 1 week before the start of harvest including the harvest period (stress before and during harvest), for field grown 'Dubloon' muskmelons in Bourke, New South Wales (2001 harvest season).

\section{Fruit harvesting and processing}

Physiologically mature fruit (at abscission or full-slip) from both experiments were harvested daily (7 to 18 May 2001 for Expt. 1 and 9 to 18 Feb. 2002 for Expt. 2). The average number of fruit per plant was calculated to be between about 2 and 3 fruit (Expt. 1: no stress 3.1 fruit per plant, stress before harvest 2.4, stress before and during harvest 3.1; Expt. 2: no stress 1.9 , stress during harvest 2.0 , stress before harvest 1.8 , stress before and during harvest 1.9). Each fruit was weighed, and the total fresh weight of fruit per 2-m subplot was converted into yield $\left(\mathrm{t} \cdot \mathrm{ha}^{-1}\right)$. One 15 -mm-diameter core of tissue was taken from an equatorial position on each side of each muskmelon, with the ground spot facing downward. The outer $10 \mathrm{~mm}$ of tissue was removed (included skin and green) then the next $10 \mathrm{~mm}$ of tissue was sampled, crushed in a hand operated garlic press and the SSC ( ${ }^{\circ}$ Brix scale) of the resulting juice measured on a Bellingham and Stanley (Kent, U.K.) RFM 320 temperature compensated digital refractometer.

Data analysis. The SAS 6.12 software package (Cary, N.C.) was used for ANOVA of data. least significant difference ( $\mathrm{LSD}, P=0.05)$ was calculated to facilitate means separation for ANOVA models that were significant $(P$ $<0.05)$. Mean and standard error values are reported where the corresponding ANOVA model was not significant $(P>0.05)$.

\section{Results and Discussion}

There was no rain during the treatment periods for Expt. 1, and only $0.8 \mathrm{~mm}$ just before the start of harvest for Expt. 2. deficit was implemented immediately before and during harvest produced fruit significantly lower in SSC than those plants delivered
In Expt. 1, treatments in which an irrigation

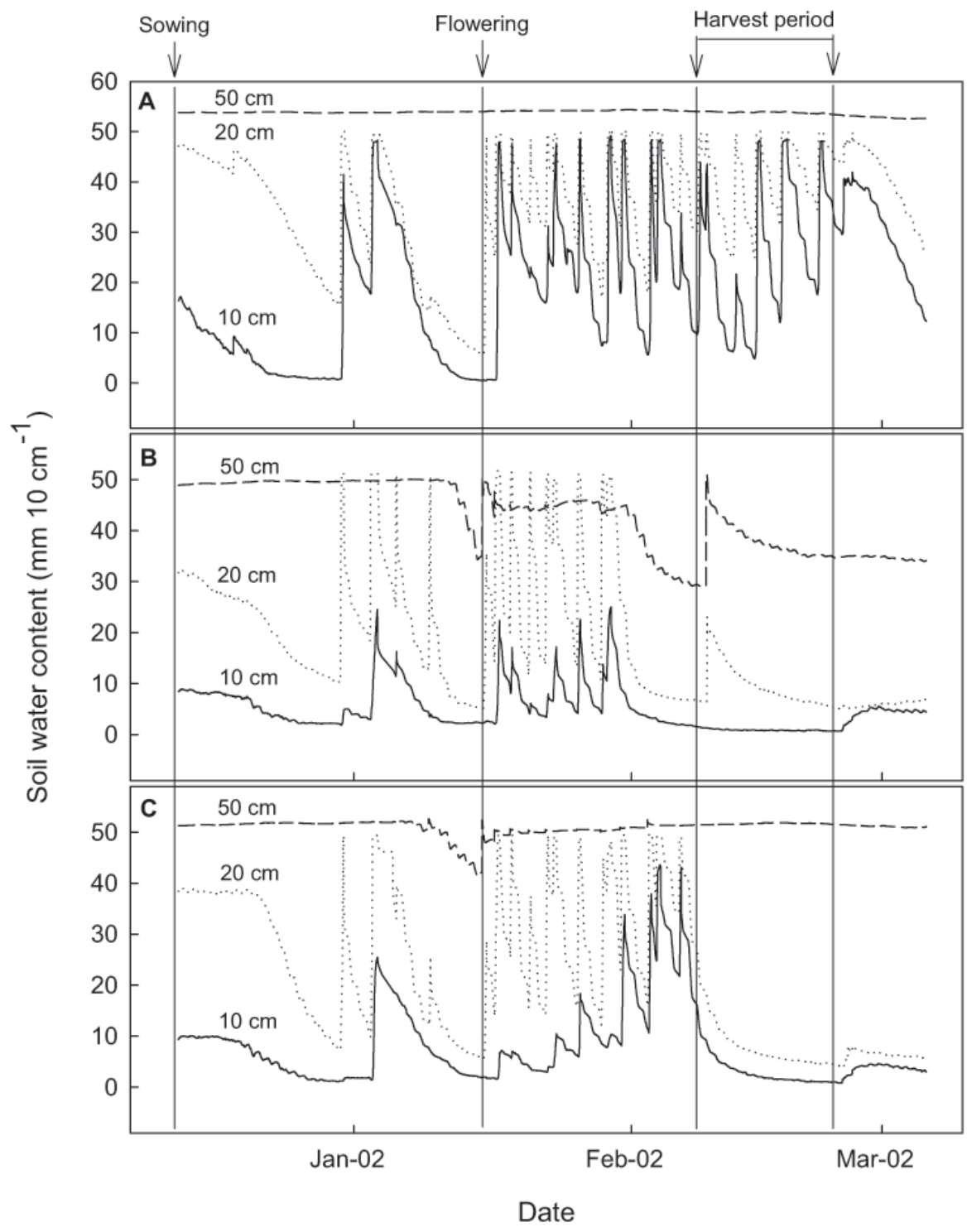

Fig. 2. Experiment 2. Soil moisture ( $\mathrm{mm} \mathrm{H}_{2} \mathrm{O}$ per $10 \mathrm{~cm}$ soil depth) for a trial in Bourke, New South Wales (2002 harvest season) recorded by Enviroscan (Sentek Australia) probes at 10, 20 and $50 \mathrm{~cm}$, for deficit (stress) free irrigation from flowering through to the end of harvest (A); for stress during the week before harvest and including the harvest period (B); and for stress implemented at the start of harvest (C). Field capacity was determined to be $50 \mathrm{~mm}$ of soil water, and the refill point was $15 \mathrm{~mm}$. Note, treatments are common to Fig. 3, and the 'stress before harvest' Enviroscan graph is not presented due to instrument malfunction and lost data. 


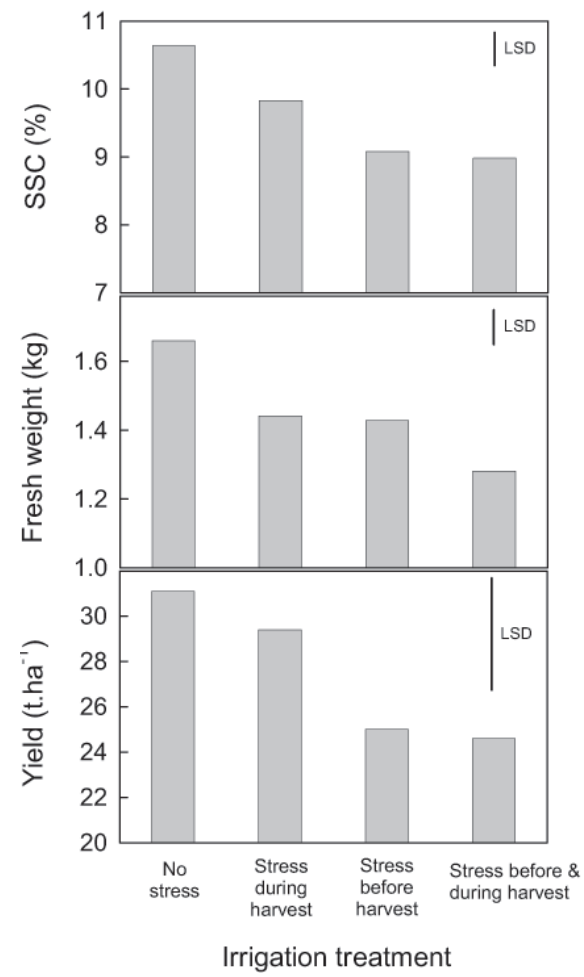

Fig. 3. Experiment 2. Mean and $\operatorname{LSD}(P=0.05)$ values for fruit soluble solids concentration (SSC), fresh weight and yield (ANOVA $P<0.05$ ). Irrigation deficit treatments were imposed at the start of harvest (stress during harvest), during the week before the start of harvest (stress before harvest), and during the week before harvest and including the harvest period (stress before and during harvest), for field grown 'Dubloon' muskmelons in Bourke, New South Wales (2002 harvest season). Data are common to Fig. 2.

adequate water during harvest (no stress $11.2 \%$ SSC, stress before harvest $8.8 \%$ SSC, stress before and during harvest $9.5 \%$ SSC) (Fig. 1). Tensiometers were maintained at 40 $\mathrm{kPa}$ during the 'stress' period, which was in accord with the Queensland Department of Primary Industry's recommended level of 25 to $40 \mathrm{kPa}$ for sandy loam soil during the week before harvest and during harvest (Lovatt et al., 1997). This irrigation deficit also reduced fruit weight and total yield, but the difference between treatments for the latter was not significant (Fig. 1).

In Expt. 2, the record of soil water content (Fig. 2) confirmed that the treatments effectively controlled available soil water for the crop. Similar effects on SSC and fresh weight were recorded as in the previous year's experiment. When an irrigation deficit was applied during either the harvest period, before harvest, or during both, fruit SSC was reduced compared to plants maintained with adequate water (e.g., no stress $10.6 \%$ SSC cf. $9.0 \%$ SSC for fruit from treatments with stress before and during harvest, Fig. 3). Fruit weight and total yield were also detrimentally affected; no stress fruit fresh weight $1700 \mathrm{~g}$, yield $31 \mathrm{t} \cdot \mathrm{ha}^{-1}$; stress before and during harvest fruit fresh weight 1300 g, yield 25 t ha ${ }^{-1}$ (Fig. 3).

The practice of allowing soil moisture to deplete close to and during harvest as recommended by Lovatt et al. (1997) and Hulme et al. (2002) reduced fruit quality in our experiments. Moisture stress during this critical period of sugar accumulation in the fruit was likely to have reduced assimilate supply to the fruit by slowing the rate of photosynthesis in the source leaves, reducing sugar accumulation. A secondary effect noticed in both experiments was that fruit from water stress treatments abscised earlier than well-watered treatments (data not shown).

The common practice of reducing irrigation close to harvest may be an over-response to reported negative effects of excessive irrigation close to harvest. Lester et al. (1994) showed that additional water close to harvest produced fruit with lower SSC and greater volume, whilst Wells and Nugent (1980) demonstrated that rainfall events close to harvest detrimentally affected muskmelon fruit SSC (depending on cultivar). Further, with a sudden improvement in plant water potential, fruit storage cells may become hyperosmotic relative to their apoplast, leading to an uptake of water into these cells and the increase in fruit fresh weight, but the dilution of accumulated sugar.

Water-logging causes root anoxia and impedes root respiration (Barrett-Lennard, 2003) which in turn slows the uptake of water, causes stomata to close and ultimately retards photosynthesis (Lester et al., 1994). Kroen et al. (1991) reported that muskmelon plants subjected to root flooding for $4 \mathrm{~d}$ close to harvest showed decreased root respiration (by $30 \%$ ) and decreased sucrose accumulation in fruit (by $36 \%$ and $88 \%$ for inner and outer mesocarp tissue, respectively). The decrease in the rate of sugar accumulation in the fruit was attributed to an increase in the glycolytic activity of the anaerobic roots and the subsequent increased transfer of carbohydrates to the roots at the expense of the fruit (Kroen et al., 1991; Su et al., 1998).

Future work on irrigation scheduling should focus on the periods preharvest and during harvest, and should include studies encompassing irrigation scheduling on different soil types and for different muskmelon cultivars.

\section{Literature Cited}

Australian Melon Association. 2003. 2003-2008 Strategic plan for the Australian Melon Industry. Austral. Melon Assn., Brisbane.

Barrett-Lennard,E.G. 2003. The interaction between waterlogging and salinity in higher plants: Causes, consequences and implications. Plant Soil 253:35-54.

El-Keblawy, A. and J.Lovett-Doust. 1996. Resource re-allocation following fruit removal in cucurbits: Patterns in canteloupe melons. New Phytol. 134:413-422.

Heermann, D.F., D.L. Martin, R.D. Jackson, and E.C. Stegman. 1990. Irrigation scheduling controls and techniques, p. 509-535. In: B.A. Stewart and D.R. Nielsen (eds.). Irrigation of agricultural crops. Madison, Wis.

Higashi, K., K. Hosoya, and H. Ezura. 1999. Histological analysis of fruit development between two melon (Cucumis melo $\mathrm{L}$. retriculatus) genotypes setting a different size of fruit. J. Expt. Bot. 50:1593-1597.

Hulme, J., M. Hickey, R. Hoogers, and G. Kelly. 2002. Best management guidelines for irrigation of melons. New South Wales Agriculture, Yanco.

Kader, A.A. 2002. Standardization and inspection of fresh fruits and vegetables, p. 287-299. In: A.A. Kader (ed.). Postharvest technology of horticultural crops. Univ. Calif., Oakland.

Kroen, W.K., D.M. Pharr, and S.C. Huber. 1991. Root flooding of muskmelon (Cucumis melo L.) affects fruit sugar concentration but not leaf carbon exchange rate. Plant Cell Physiol. 32:467-473.

Lester, G.E., N.F. Oebker, and J. Coons. 1994. Preharvest furrow and drip irrigation schedule effects on postharvest muskmelon quality. Postharvest Biol. Technol. 4:57-63.

Lester, G.E., Arias, L.S. and Gomez-Lim, M. 2001. Muskmelon fruitsolubleacid invertase and sucrose phosphate synthase activity and polypeptide profiles during growth and maturation. J. Amer. Soc. Hort. Sci 126:33-36.

Long, R.L., K.B. Walsh, G. Rogers, and D.J. Midmore. 2004. Source-sink manipulation to increase melon (Cucumis melo L.) fruit biomass and soluble sugar content. Austral. J. Agr. Res. 55:1241-1251.

Lovatt, J., R. Wright, N. Meurant, L. Vawdrey, and J. Hojmark-Anderson. 1997. Rockmelon and honeydew information kit. Queensland Dept. Primary Ind., Brisbane.

Muldoon, D., M. Hickey, R. Hooger, M. Aleemullah, and A. Ashcroft. 1999. Rooting depth of irrigated rockmelons on clay soils. Farmers' Nwsltr.-Hort. 183:17-18.

Mutton, L.L., B.R. Cullis, and A.B. Blakeney. 1981. The objective definition of eating quality in rockmelons (Cucumis melo). J. Sci. Food Agr. 32:385-390.

Phene, C.J., K.R. Davis, R.L. McCormick, A. Pincot, and D.W. Meek. 1987. Evapotranspiration and irrigation scheduling of drip irrigated muskmelons. Intl. Winters Mtg. Amer. Soc. Agr. Eng. Paper 87-2526.

Su, P.H., T.G. Wu, and C. Lin. 1998. Root sugar level in luffa and bitter melon is not referential to their flooding tolerance. Bot. Bul. Acad. Sin. 39:175-179.

Valantin, M., C. Gary, B.E. Vaissiere, M. Tchamitchian, and B. Bruneli. 1998. Changing sink demand affects the area but not the specific activity of assimilate sources in muskmelon (Cucumis melo L.). Ann. Bot. 82:711-719.

Wein, H.C. 1997. The cucurbits: Cucumber, melon, squash, and pumpkin, p. 345-386. In: The physiology of vegetable crops. CABI Publ., New York.

Wells, J.A. and P.E. Nugent. 1980. Effect of high soil moisture on quality of muskmelon. HortScience $15: 258-259$. 